\title{
Effect of ageing on beta-cell mass and function in rats malnourished during the perinatal period
}

\author{
A. Garofano, P. Czernichow, B. Bréant \\ INSERM U 457, Hôpital Robert Debré, Paris, France
}

\section{Abstract}

Aims/hypothesis. In a recently developed rat model, maternal food restriction from day 15 of pregnancy until weaning induced low birth weight and a $70 \%$ reduction of beta-cell mass in the offspring at day 21 after birth. Subsequent renutrition from weaning was insufficient to fully restore beta-cell mass in young adult rats. The aim of this study is to investigate the long-term consequences of early malnutrition on beta-cell mass and function.

Methods. Oral glucose tolerance tests were done in 3and 12-month-old animals and beta-cell mass and apoptosis were determined by morphometrical measurements on pancreatic sections. The specific impact of postnatal malnutrition was studied by comparing control animals (C group) with animals malnourished during their fetal life only ( $\mathrm{R} / \mathrm{C}$ group), and animals malnourished during fetal life and until weaning ( $\mathrm{R}$ group).

Results. In 3-month-old $\mathrm{R} / \mathrm{C}$ animals beta-cell mass reached $8.0 \pm 1.5 \mathrm{mg}$ with no further increase un- til 12 months $(8.1 \pm 1.5 \mathrm{mg})$, compared with $9.3 \pm$ $1.9 \mathrm{mg}$ in control rats. Twelve-month-old $\mathrm{R} / \mathrm{C}$ animals showed normal plasma insulin responses and borderline glucose tolerance. In $\mathrm{R}$ animals, apoptosis reached $1.9 \pm 0.4 \%$ of the beta cells at 3 months, compared with $0.7 \pm 0.5 \%$ in control rats, and betacell mass did not increase between 3 and 12 months ( $4.7 \pm 0.8 \mathrm{mg}$ at 12 months). In aged control and $\mathrm{R}$ animals, apoptosis affected $8 \%$ of the beta cells. At 12 months only, R animals showed profound insulinopenia and marked glucose intolerance.

Conclusion/interpretation. In conclusion, perinatal malnutrition profoundly impairs the programming of beta-cell development. In animals with decreased beta-cell mass the additional demand placed by ageing on the beta cells entails glucose intolerance since beta-cell mass does not expand and apoptosis is increased. [Diabetologia (1999) 42: 711-718]

Keywords Malnutrition, ageing, beta-cell mass, apoptosis, glucose tolerance.
Numerous processes, including deterioration of insulin secretion, insulin resistance, glucose intolerance as well as reduction of beta-cell mass, occur during ageing in humans and animals [1-4]. Clinical studies have reported a higher risk of developing glucose intolerance or insulin resistance at late adult age in sub-

Received: 16 November 1998 and in revised form: 15 January 1999

Corresponding author: Dr. B. Bréant, INSERM U 457, Hôpital Robert Debré, 48 boulevard Sérurier, F-75019 Paris, France Abbreviations: IUGR, intra-uterine growth retardation. jects born with intra-uterine growth retardation (IUGR) [5-8] and more so in those who did not catch-up in growth at 1 year of age [5]. The mechanisms linking low birth weight and glucose intolerance are at present not known but an exciting hypothesis has suggested that in utero malnutrition could lead to a reduction in the number of beta cells [9] which would be insufficient to fulfill the insulin requirements imposed by ageing. We have recently described a rat model of IUGR induced by maternal food restriction from day 15 of pregnancy until the end of lactation [10]. At weaning on day 21 after birth, the offspring showed a $70 \%$ reduction in beta- 
cell mass [11]. Subsequent renutrition from weaning was insufficient to fully restore beta-cell mass at 3 months of age. Despite a slightly decreased insulinaemia these animals have fasting glucose concentrations in the normal range [11]. Animal models of diabetes, such as the GK rat [12-14] or of diabetes induced by streptozotocin treatment in rats [15-18] have shown that beta-cell reduction often precedes glucose intolerance or impairment of insulin secretion in adult life. The purpose of this study is to investigate the long-term consequences of early malnutrition and more specifically to determine if ageing, by increasing the insulin demand on the beta cells, would have deleterious effects on beta-cell function in animals with a decreased beta-cell mass. To that end, oral glucose tolerance tests were done in 3month- and 12-month-old animals and beta-cell mass was determined by morphometrical measurements on pancreatic sections. More specifically, the extent of apoptosis in the beta cells, a process recently shown to participate in the remodeling of the endocrine pancreas [19-23], was investigated. The further impact of postnatal malnutrition was studied by comparing animals born with IUGR and normally nourished after birth ( $\mathrm{R} / \mathrm{C}$ group) with animals born with IUGR and malnourished until weaning ( $\mathrm{R}$ group).

The objectives were thus to study the consequences of fetal and early postnatal malnutrition compared with malnutrition in fetal life only on the evolution of glucose tolerance and beta-cell mass at adult age and during ageing. A considerable impairment of both beta-cell mass and glucose tolerance was observed during ageing when malnutrition occured until weaning, whereas fetal malnutrition had moderate consequences.

\section{Materials and methods}

Animals and study design. Three month-old pregnant Wistar rats (day 12 of pregnancy) were purchased from Janvier breeding centre (le Genêt-St. Isle, France). The female rats were caged individually with free access to tap water. The room was maintained at a constant temperature $\left(22^{\circ} \mathrm{C}\right)$ with a $12 \mathrm{~h}$ light-dark cycle. All pregnant rats were fed a standard laboratory rat chow and randomly assigned to either the control or restricted group. Maternal food restriction (50\% of the ad libitum intake) was established from day 15 of pregnancy as described previously [10]. At parturition, pups from 10 (control) or 16 (restricted) litters were immediately weighed, the size of the litters was equalized ( 8 pups/litter) and the neonates with severe intrauterine growth retardation (body weight $\leq$ control body weight -2 SD) were selected (mean birth weight $5.2 \pm 0.2 \mathrm{~g}, n=94$ ). Control pups (mean birth weight $6.2 \pm 0.5$ $\mathrm{g}, n=98)$ were not selected.

Three groups of male animals were studied: animals born and nursed by control mothers ( $\mathrm{C}$ group, body weight $54.1 \pm 3.6 \mathrm{~g}$ at weaning), animals born by food-restricted mothers and nursed by food-restricted mothers ( $\mathrm{R}$ group, body weight $28.3 \pm 2.2 \mathrm{~g}$ at weaning), animals born by food-restricted mothers and nursed by control mothers ( $\mathrm{R} / \mathrm{C}$ group, body weight $51.4 \pm 3.8 \mathrm{~g}$ at weaning). After weaning, all animals were fed ad libitum throughout the experience. The three groups of male rats were studied at 3 and 12 months of age. At each time point, the animals were randomly chosen and killed by cervical dislocation. Their body and pancreatic weight is given in Table 1 . These studies were approved by the French animal ethics committee.

Tissue processing. For immunohistochemistry, four animals of each group were analysed at 3 and 12 months of age respectively. The whole pancreas was excised, cut into three parts corresponding to the head (i.e. duodenal side), median (body) and tail (i.e. spleen side), which were separately fixed in paraformaldehyde and processed, as described previously [11]. Each piece of pancreas was sectioned lengthwise $(6 \mu \mathrm{m}$ thick sections). Every 42th section of 3 and 12 months old animals was analysed, yielding five to seven sections from each portion of pancreas. The median part was not analysed.

Immunohistochemistry. Beta cells were detected with a guinea pig polyclonal anti-insulin antibody (1:200, Dako, Trappes, France) for $2 \mathrm{~h}$ at $37^{\circ} \mathrm{C}$, followed by incubation with an alkaline phosphatase anti-rabbit antibody (1:100, Promega, Lyon, France) and visualized in blue with nitroblue tetrazolium (NBT; Vector, Compiègne, France). Previous experiments had shown that these methods allowed the detection of all insulin-positive cells [11]. Controls for immunostaining consisted of the omission of the primary antibodies, and these tests resulted in negative staining reactions.

Beta-cell apoptosis. Beta-cell death was determined using the Terminal transferase-mediated X-dUTP Nick end Labelling (TUNEL) method with the Apoptag S 7100 kit (Oncor, Illkirch, France). Apoptotic nuclei were stained in brown with 3, 3 '-Diaminobenzidine (DAB; Sigma, La Verpillière, France). Non-beta cells ( $\alpha, \delta$ and PP cells) were visualized with a cocktail of mouse monoclonal anti-glucagon (1:1000; Sigma), rabbit anti-somatostatin (1:500; Dako, Trappes, France) and rabbit anti-PP (1:500; Eurodiagnostica, Gentilly, France) antibodies, followed with alkaline phosphatase-conjugated appropriate secondary antibodies and visualized in red with fast red (Sigma). The sections were lightly counterstained to visualize cell nuclei.

Morphometry. Beta-cell fraction was determined by computer assisted measurements with a Leica DMRB microscope equipped with a colour video camera connected to a Quantimet 500 MC computer (screen magnification $\times 24$ ), as described previously [11]. Briefly, the area of insulin-positive cells was measured on the entire section and beta-cell fraction was calculated in each section as the ratio of insulin-positive area to the total area of the tissue section. Absolute beta-cell mass per pancreas was calculated as the product of mean beta-cell fraction by the corresponding pancreatic weight. Data from five to seven sections per pancreas were averaged for each pancreas.

Beta-cell apoptosis was determined in the tail part of the pancreas as the ratio of the apoptotic nuclei to the total intraislet nuclei which were negative for glucagon, somatostatin and PP, as described previously by others [19]. Data from four to five islets per section, randomly chosen from three to four sections, were measured for each pancreas, at a final magnification $\times 960$, wich yielded at least 12000 counted cells per animal.

Oral glucose tolerance tests. Three and 12 month-old rats were fasted for $6 \mathrm{~h}$ before being orally injected with a $2 \mathrm{~g} / \mathrm{kg}$ body weight glucose solution $(\mathrm{D}(+)$ glucose monohydrate: Merck, 
A
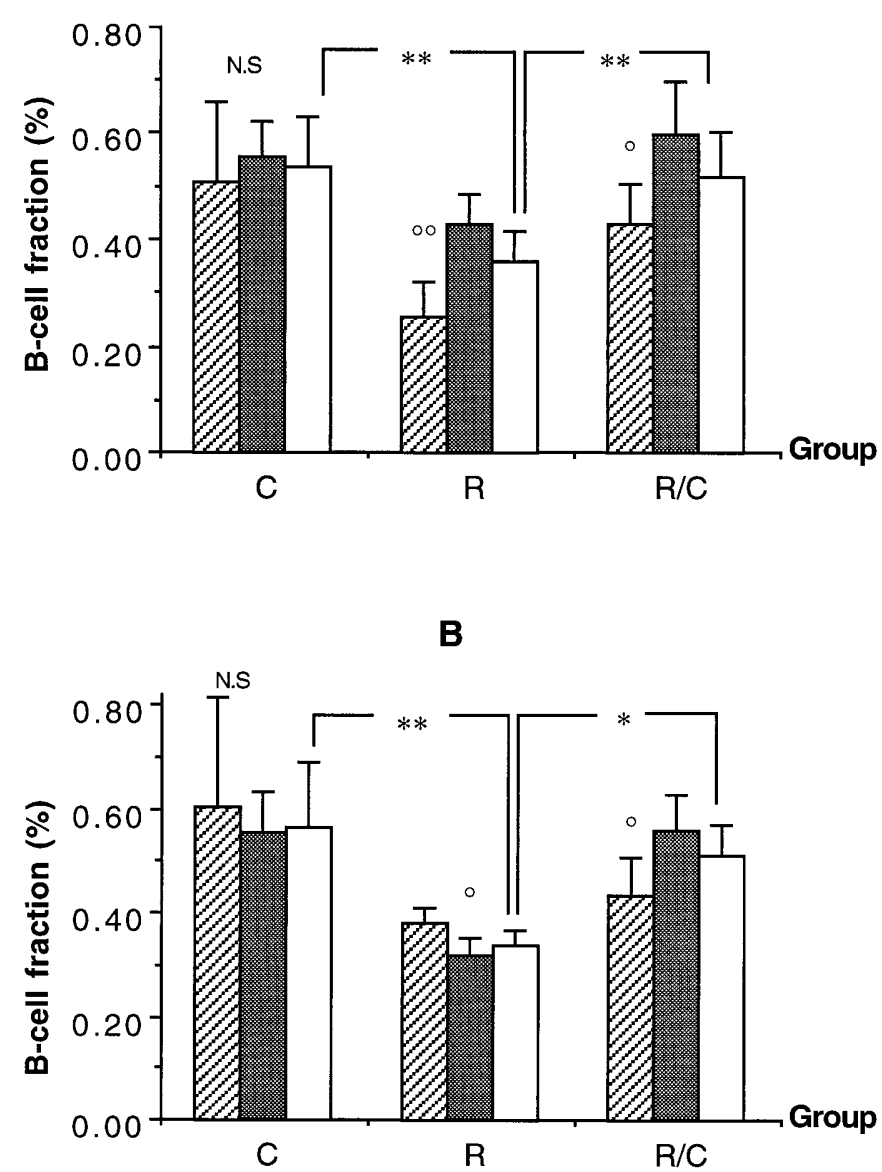

Fig. 1A, B. Beta-cell fraction in 3 month- (panel $\mathbf{A}$ ) and 12 month-old (panel B) animals. Beta-cell fraction in the head Wh, in the tail of the pancreas and mean beta-cell fraction $\square$, in $\mathrm{R}$ (fetal + postnatal malnutrition), R/C (fetal malnutrition) and $\mathrm{C}$ (control) animals. ** $p \leq 0.01, * p \leq 0.05$ : mean beta-cell fraction compared with two different groups $(n=4)$. ${ }^{\circ} p \leq 0.01,{ }^{\circ} p \leq 0.05$ : beta-cell fraction in the head compared with tail part of the pancreas in the same group

Paris, France). Blood samples were collected from the rat tail into heparinized tubes at time 0 and 15, 30, 60, 120 min after the glucose load. Blood glucose was determined with the glucose oxidase technique using a glucometer One Touch II (Lifescan, Roissy, France). Plasma samples were stored at $-20^{\circ} \mathrm{C}$ until processed. Plasma insulin was measured by radioimmunoassay using monoiodinated ${ }^{125}$ I-labelled porcine insulin as tracer (Sorin Biomedica, Saluggia, Italy), guinea pig anti-insulin antibody kindly provided by Dr. Van Schravendijk (Brussels, Belgium) and purified rat insulin as standard (Novo, Boulogne, France). Charcoal was used to separate free from bound hormone. The sensitivity of the assay was $0.25 \mathrm{ng} / \mathrm{ml}(6 \mu \mathrm{U} /$ $\mathrm{ml})$.

Statistical analysis. Values are expressed as means \pm SD. Fasting insulin and glucose concentrations, reflecting the longterm basal metabolism, were tested separately. Glucose tolerance was evaluated by the areas under the curve (AUC) for insulin and glucose during OGTT. Differences between the three groups for continuous variables were analysed using ANOVA, followed by Fisher's PLSD or Bonferroni/Dunn between two

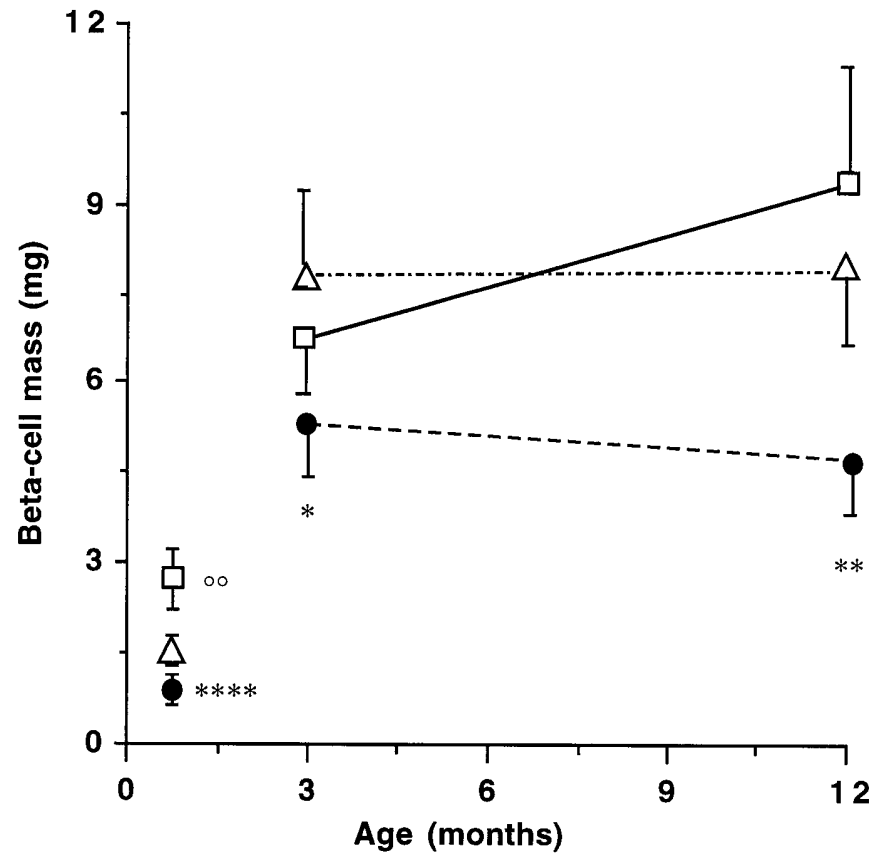

Fig. 2. Evolution of beta-cell mass from weaning to adulthood. $\mathrm{R}$ animals - - - (malnutrition until weaning), $\mathrm{R} / \mathrm{C}$ animals $\cdot-\cdot \triangle \cdot \cdot \cdot$ (malnourished during their fetal life only), and control animals $\square \square$. Values of beta-cell mass at weaning are those described in [11] for $\mathrm{R}$ animals (**** $p \leq 0.0001$, compared with control rats) and in [25] for $\mathrm{R} / \mathrm{C}$ animals ( ${ }^{\circ}$ $p \leq 0.01$, compared with control rats). ** $p \leq 0.01$, * $p \leq 0.05$ : R group $(n=4)$ compared with control rats $(n=4)$ by ANOVA

groups. Data were entered using Statview Package (Abacus System, Meylan, France). A $p$-value less than 0.05 was considered significant.

\section{Results}

Beta-cell fraction. In adult control rats (C group), mean beta-cell fraction did not vary with age and was similar in the head and in the tail of the pancreas (Fig.1A,B). In animals malnourished during their fetal life only ( $\mathrm{R} / \mathrm{C}$ group), mean beta-cell fraction was not statistically different from control rats, both at 3 and 12 months of age. In the head of the pancreas, however, it was reduced at both ages, compared with control animals. In animals malnourished during their fetal and early postnatal life ( $\mathrm{R}$ group), mean beta-cell fraction was decreased by $34 \%$ at 3 months (Fig. 1A) and by $42 \%$ at 12 months (Fig.1B), compared with control rats. This decrease prevailed in the head of the pancreas at 3 months of age (Fig.1A), whereas it was also clearly observed in the tail at 12 months of age (Fig. 1B).

Beta-cell mass. In control animals, absolute beta-cell mass showed a 2.5 -fold increase between 3 weeks and 3 months of age and increased by nearly $40 \%$ between 3 and 12 months of age (Fig. 2, Table 1). A 
Table 1. Body and pancreas weight, beta-cell mass and metabolic data

\begin{tabular}{|c|c|c|c|c|c|c|}
\hline \multirow[t]{2}{*}{ Group } & \multicolumn{3}{|l|}{3 Months } & \multicolumn{3}{|l|}{12 Months } \\
\hline & $\mathrm{C}$ & $\mathrm{R}$ & $\mathrm{R} / \mathrm{C}$ & $\mathrm{C}$ & $\mathrm{R}$ & $\mathrm{R} / \mathrm{C}$ \\
\hline Body weight (g) & $461 \pm 51$ & $375 \pm 33^{d}$ & $438 \pm 46$ & $664 \pm 41$ & $574 \pm 11^{\mathrm{d}, \mathrm{g}}$ & $663 \pm 30$ \\
\hline Beta-cell mass (mg) & $6.72 \pm 0.91$ & $5.64 \pm 0.50^{\mathrm{d}, \mathrm{g}}$ & $8.01 \pm 1.50$ & $9.35 \pm 1.91$ & $4.72 \pm 0.8^{\mathrm{c}, \mathrm{f}}$ & $8.07 \pm 1.48$ \\
\hline Fasting glycaemia (mmol/l) & $3.92 \pm 0.29$ & $4.01 \pm 0.35$ & $3.77 \pm 0.20$ & $5.05 \pm 0.27$ & $5.46 \pm 0.15^{\mathrm{c}}$ & $5.58 \pm 0.17^{b}$ \\
\hline Fasting insulin $(\mathrm{nmol} / \mathrm{l})$ & $0.51 \pm 0.16$ & $0.40 \pm 0.08$ & $0.33 \pm 0.06^{\mathrm{d}}$ & $0.38 \pm 0.14$ & $0.22 \pm 0.08^{\mathrm{c}, \mathrm{e}}$ & $0.48 \pm 0.06$ \\
\hline AUC glycaemia $(\mathrm{min} \cdot \mathrm{mmol} / \mathrm{l})$ & $631.7 \pm 19.6$ & $632.6 \pm 34.0$ & $621.6 \pm 9.2$ & $746.1 \pm 43.4$ & $838.9 \pm 57.0^{\mathrm{b}}$ & $793.1 \pm 15.5$ \\
\hline \multicolumn{3}{|c|}{$\begin{array}{l}\text { Values for body weight, pancreas weight and beta-cell mass are } \\
\text { mean } \pm \text { SD of four different animals in each group and age. } \\
\text { OGTT, shown in Fig. } 4 \text { and 5, were carried out with } 15 \text { animals, } \\
\text { except for } 3 \text {-month-old R/C animals }(n=10) \text { and } 12 \text {-month- } \\
\text { old R/C animals }(n=5) \text {, malnourished during their fetal life }\end{array}$} & \multicolumn{4}{|c|}{$\begin{array}{l}\text { and until weaning. Data were first analyzed by ANOVA, fol- } \\
\text { lowed by Fisher's PLSD or Bonferroni/Dunn between two } \\
\text { groups. }{ }^{\mathrm{a}} p \leq 0.0001,{ }^{\mathrm{b}} p \leq 0.001,{ }^{\mathrm{c}} p \leq 0.01,{ }^{\mathrm{d}} p<0.05 \text {, com- } \\
\text { pared with age-matched control animals (C). }{ }^{\mathrm{e}} p \leq 0.001 \text {, } \\
{ }_{\mathrm{f}} p \leq 0.01,{ }^{\mathrm{g}} p<0.05 \text {, compared with R/C }\end{array}$} \\
\hline
\end{tabular}
only. $\mathrm{R}$ animals had been malnourished during their fetal life

striking catch-up in beta-cell mass (5-fold increase) was observed in $\mathrm{R} / \mathrm{C}$ animals between 3 weeks and 3 months of age, greater than that of control animals during the same time period (Fig. 2). At 3 months of age, R/C animals showed an identical number of beta cells per islet section in the head and in the tail (results not shown), similar to that described previously for age-matched control animals [11]. From 3 months onwards, beta-cell mass did not increase anymore in the $\mathrm{R} / \mathrm{C}$ animals and absolute values were not statistically different from those of control animals (Fig. 2, Table 1).

In $\mathrm{R}$ animals malnourished until weaning, betacell mass increased rapidly from weaning to 3 months of age but growth was stunted between 3 and 12 months. As a consequence, a $50 \%$ decreased beta-cell mass was observed at 12 months, compared with controls rats (Fig. 2, Table 1). Moreover, many large islets from 12-month-old $\mathrm{R}$ animals showed very weak or disrupted immunostaining for insulin, suggesting deep degranulation of a large proportion of the remaining beta cells at that age (Fig.3C,D). These weakly insulin-positive cells, however, remained detectable for measurement of beta-cell mass.

The number of beta cells per islet section was not statistically different between the three groups of animals at 12 months of age and no regional variation was observed between the head and the tail (data not shown).

Beta-cell apoptosis. Beta cells from 3-month-old R animals have been shown to proliferate at a higher rate than those from control animals [11]. The stunting of beta-cell growth observed between 3 and 12 months of age could thus arise from increased beta-cell death. Apoptosis was very low in 3-monthold control rats $(0.70 \pm 0.53 \%$ of the beta cells, Fig. 3A) whereas it increased threefold (1.92 \pm $0.39 \%$ ) in $\mathrm{R}$ animals, $p$ equal or less than 0.001 ,
(Fig.3B). Ageing increased apoptosis in the beta cells, both in control $(7.8 \pm 1.7 \%$ of the beta cells) and $\mathrm{R}$ animals $(8.3 \pm 1.7 \%)$, but no differences were observed between the two groups at that age. Betacell apoptosis was not determined in $\mathrm{R} / \mathrm{C}$ animals.

Oral glucose tolerance tests. At 3 months of age, animals malnourished during their fetal and early postnatal life showed a normal glycaemic response to the oral glucose load, despite a significantly decreased insulin response (Fig. 4A-B, Table 1). At 12 months of age, these animals showed increased fasting glycaemia and dramatically impaired glucose tolerance, associated with a profound insulinopenia, before and during OGTT (Fig.4C-D, Table 1), compared with age-matched control animals. Ageing also increased fasting glycaemia $(p<0.0001)$ and impaired glucose tolerance $(p<0.0001)$ in control animals.

Normal glucose tolerance was observed in 3month-old $\mathrm{R} / \mathrm{C}$ animals malnourished during their fetal life only (Fig. 5A), with a tendancy to decreased insulin response during OGTT $(p=0.10)$ compared with control rats (Fig. 5B, Table 1). In 12-month-old $\mathrm{R} / \mathrm{C}$ animals, fasting glycaemia was increased. Glucose tolerance, as evaluated by the AUC was not considerably increased (Table 1$)$ due to the small number of animals in this age group $(p=0.08)$, differences being mostly observed in the early response to the oral glucose load, with plasma insulin concentrations similar to those of control animals (Fig. 5C,D).

Fig.3A-D. Morphological changes in adult previously malnourished $\mathrm{R}$ animals. Apoptosis is increased in the beta cells from 3-month-old previously malnourished $\mathrm{R}$ animals (B), compared with age-matched control rats $(\mathbf{A})$; original magnification $\times 200$. During ageing (12 months of age) many islets from $\mathrm{R}$ animals show disorganized architecture or weak insulin immunostaining $(\mathbf{C}$ and $\mathbf{D})$; original magnification $\times 100$ 

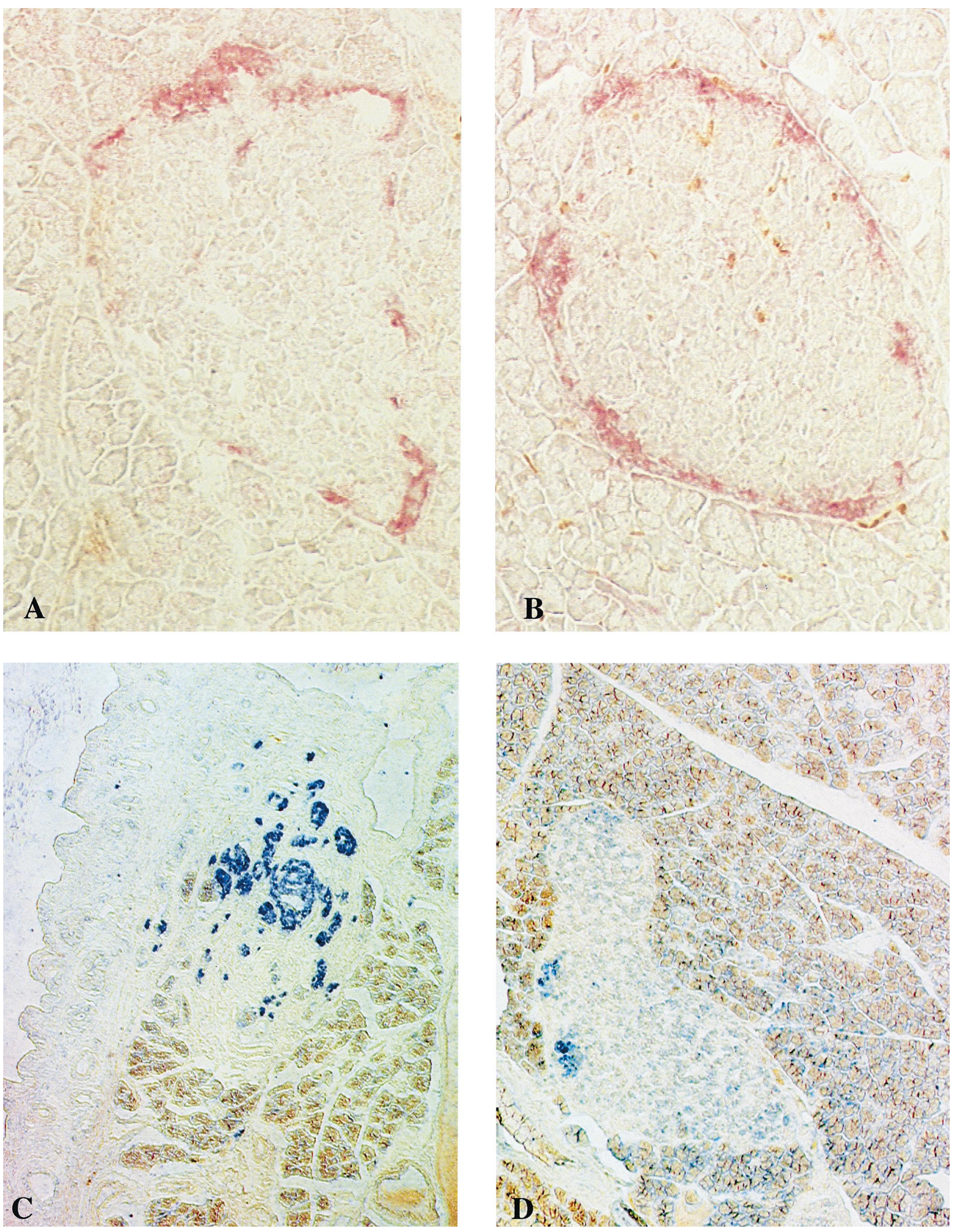

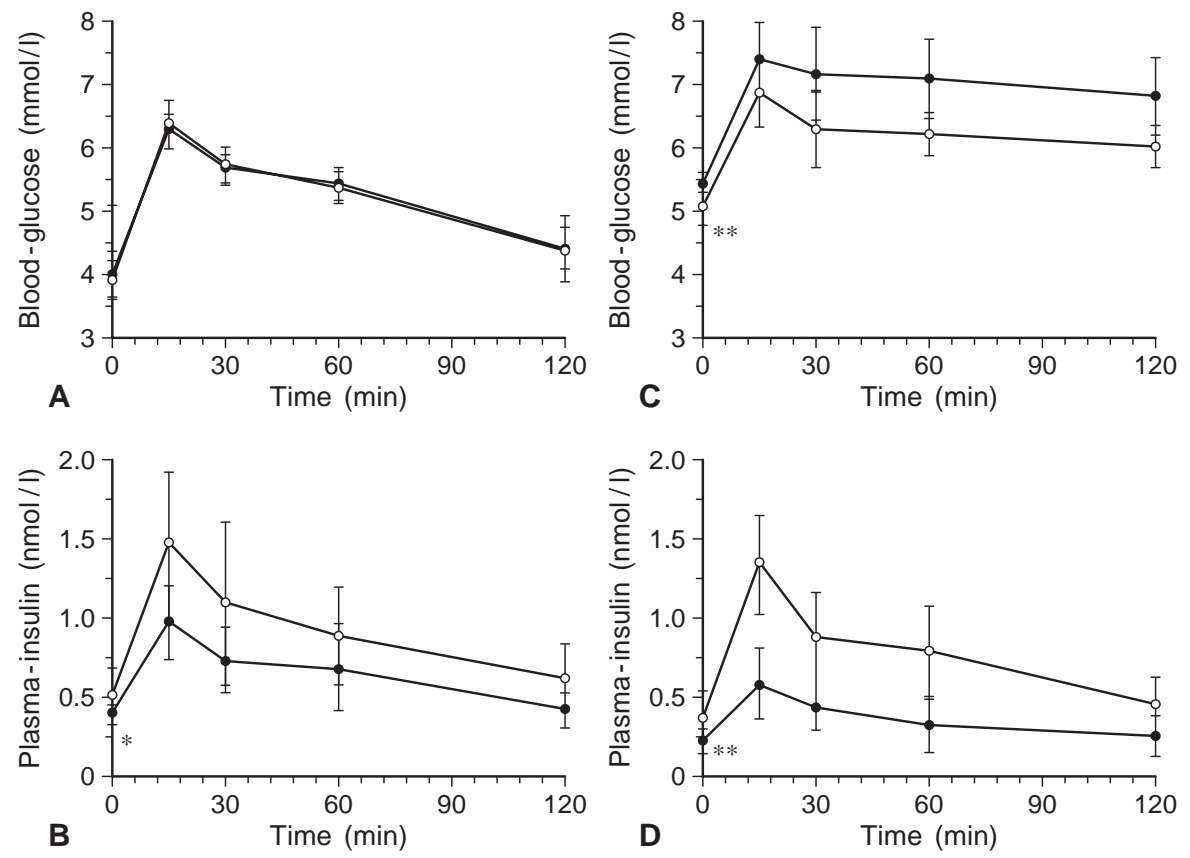

Fig. 4A-D. OGTT curves at 3 and 12 months of age in control and $\mathrm{R}$ animals. Animals $(n=15)$ were orally injected with a dose of $2 \mathrm{~g} / \mathrm{kg}$ glucose solution. Upper panels show the evolution of blood glucose at $3(\mathbf{A})$ and 12 months of age $(\mathbf{C})$ and lower panels the evolution of plasma insulin at 3 (B) and 12 months of age (D). - - C C Control animals ; - - : R animals malnourished until weaning

\section{Discussion}

This study investigated the long-term consequences of early malnutrition on beta-cell mass and glucose homeostasis later in life. The results show that malnutrition in protein and calories during fetal life only has little consequences on beta-cell mass and slightly impairs glucose tolerance in adulthood, when there is an increased insulin demand on the beta cells due to ageing. A more dramatical outcome is observed in IUGR offspring malnourished until weaning. In this situation beta-cell growth is totally stunted between 3 and 12 months of age, forcing the remaining beta cells to overproduction and exhaustion. As a consequence, severe insulinopenia is observed and glucose intolerance develops. These findings underline the importance of adequate nutrition during lactation to develop sufficient beta-cell mass in the rat.

We have shown that $\mathrm{R}$ animals weaned and placed on a control diet showed only partial recovery of beta-cell mass at 3 months of age. This recovery was, at least partly, due to an enhancement of beta-cell proliferation which mainly occurred in the tail of the pancreas [11]. Neogenesis could also contribute to the observed recovery but the quantification of this process is not yet established [24]. Apoptosis, the third process implicated in the balance of beta-cell

mass [20] was measured. We show here that beta-cell death by apoptosis is threefold higher in previously malnourished 3-month-old $\mathrm{R}$ animals and this finding might explain the stunting of beta-cell growth between 3 and 12 months of age. A wave of apoptosis occurring in the beta-cells of the normal rat shortly before weaning has recently been described and suggested to contribute to the remodelling of the endocrine pancreas $[19,21]$, thereby eliminating a pool of cells not adequately equipped for nutrition after weaning. More generally, it has been suggested that this process would take place in other circumstances where numbers of inadequate beta cells have to be removed [22, 23]. These reports describe increased apoptosis in the normal rat pancreas of aged rats, being nearly as high as that in the neonatal rats. Further evidence is thus provided for a role of apoptosis in the remodelling of the endocrine pancreas and possibly in the elimination of old or defective beta cells. It should be acknowledged that the determination of apoptosis was indirect and thus it cannot be excluded that the high percentage of cells undergoing apoptosis at 12 months of age possibly includes other nonendocrine cell types. Negative staining for fibrosis or inflammatory cells within the islets makes this hypothesis rather unlikely. It can also be suggested that during ageing increased proliferation or neogenesis could occur to compensate for the rapid loss of beta cells by apoptosis. Although beta-cell proliferation was not measured in 12-month-old animals, the same number of beta cells per islet section at both ages suggests that proliferation is not likely to be modified in old animals. Up to now, proliferation is considered to be the only mechanism whereby beta-cell mass increases in the absence of a major external stimulus [20], but increasing efforts should be made in an at- 

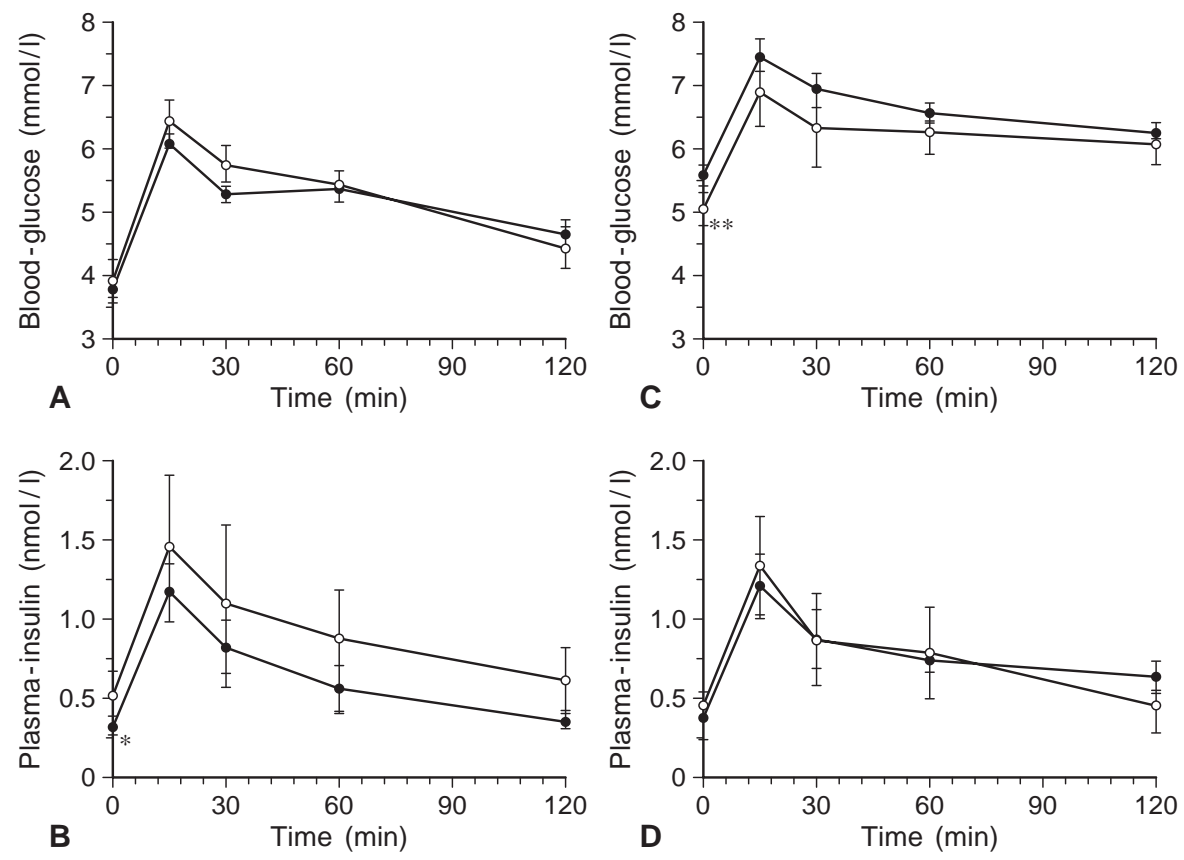

Fig. 5A-D. OGTT curves at 3 and 12 months of age in control and $\mathrm{R} / \mathrm{C}$ animals. Animals were orally injected with a dose of 2 $\mathrm{g} / \mathrm{kg}$ glucose solution. Upper panels show the evolution of blood glucose at $3(\mathbf{A})$ and 12 months of age (C) and lower panels the evolution of plasma insulin at $3(\mathbf{B})$ and 12-months of age $(\mathbf{D})$. - - - Control animals $(n=15) ;-1 \mathrm{-}$ : $/ \mathrm{C}$ animals malnourished until birth $(n=10$ at 3 months and $n=5$ at 12 months)

tempt to quantify neogenesis. In old $\mathrm{R}$ animals, proliferation was insufficient to fulfill the needs for beta-cell growth when apoptosis increased and neogenesis had been altered by in utero malnutrition [25].

Note that glucose tolerance as measured by means of OGTT, deteriorated with ageing in a fashion paralleling that of beta-cell mass in previously malnourished $\mathrm{R}$ animals. At 3 months of age, beta-cell mass was slightly reduced in $\mathrm{R}$ animals and a decreased insulin response was observed in response to the glucose challenge but the glycaemic reactions remained within the normal range. This could reflect an increased insulin sensitivity as already described in young adult animals fed a low-protein isocaloric diet during pregnancy and lactation [26]. It is well known that ageing impairs glucose tolerance by placing an additional demand on the beta cells: this results in higher fasting and 120 min glucose concentrations in control animals at 12 months of age compared with the age of 3 months, both having similar insulin responses. Animals that had been malnourished during the fetal and early postnatal stage showed at 12 months of age, and when compared with agematched control rats, a marked deterioration of glucose tolerance with profound insulinopenia, in line

with the observed degranulation of many beta cells. Although functional disorders cannot be excluded, these observations suggest that normal glycaemia cannot be achieved because of the diminished betacell mass: the overproducing remaining beta cells cannot be adequately replaced once they fail, since beta-cell development has been impaired.

Animals that were malnourished in their fetal life only (R/C group) showed a different picture. Although nursed by control mothers from birth, they had a $50 \%$ reduction of beta-cell mass at weaning [25] which recovered entirely or was even greater than that of control rats at 3 months of age. The beta-cell mass did not show any further increase with age, a common feature with $\mathrm{R}$ animals, underlining the long lasting impact of in utero malnutrition on beta-cell growth in older animals. Glucose tolerance was not impaired in 3-month-old $\mathrm{R} / \mathrm{C}$ animals in contrast with the slight intolerance observed in 70-dayold female rats fed a low protein isocaloric diet during fetal life [27]. This difference could arise from the diet itself, or from a difference in sex. Ageing impaired glucose tolerance in $\mathrm{R} / \mathrm{C}$ animals, which showed similar plasma insulin but slightly higher glycaemic concentrations than control animals at 12 months of age, suggesting that the insufficient insulin response could be associated with a slight insulin resistance.

Much attention has recently been given to the late consequences of intra-uterine malnutrition in humans. Increased death from cardiovascular disease and increased prevalence for syndrome $\mathrm{X}$ have been described [8]. More recently, increased plasma concentrations of insulin and proinsulin have been observed in a cohort of young adults born with intrauterine growth retardation [28]. These clinical obser- 
vations have generally been interpreted as a consequence of insulin resistance. It should be pointed out that our work as well as other studies about rats do not offer a valuable explanation to what has been described in humans. Results obtained in the rat born with intra-uterine growth retardation show later occurrence of hyperglycaemia and insulin deficiency rather than hyperinsulinaemia [26, 27, 29]. It cannot be excluded, however, that in rats born with IUGR, hyperinsulinaemia could be detected only within a very short period of time and was likely to take place at an earlier stage than investigated in this study.

In conclusion, perinatal malnutrition has a longtime effect on the programming of beta-cell development. The increased insulin demand imposed by ageing on the beta cells is not compensated by cell growth and glucose intolerance develops. Further work on insulin-sensitive tissues is needed, to elucidate how animal models can help understand observations made in humans.

Acknowledgements. This work was funded by the Institut National de la Santé et de la Recherche Médicale (INSERM) and a grant of the Fondation pour la Recherche Médicale. We are grateful to M.C. Castellotti for expert technical assistance and to C. Levy-Marchal for valuable comments. We also thank Novo Laboratories for financial support to A. Garofano.

\section{References}

1. DeFronzo R (1979) Glucose intolerance and aging. Evidence for tissue insentivity to insulin. Diabetes 28: 1095-1101

2. Chen M, Bergman RN, Porte D Jr (1988) Insulin resistance and $\beta$-cell dysfunction in aging: the importance of dietary carbohydrate. J Clin Endocrinol Metab 67: 951-957

3. Reaven E, Wright D, Mondon CE, Solomon R, Ho H, Reaven GM (1983) Effect of age and diet on insulin secretion and insulin action in the rat. Diabetes 32: 175-180

4. Wang SY, Halban PA, Rowe JW (1988) Effects of aging on insulin synthesis and secretion. Differential effects on preproinsulin messenger RNA levels, proinsulin biosynthesis, and secretion of newly made and performed insulin in the rat. $\mathbf{J}$ Clin Invest 81: 176-184

5. Hales CN, Barker DJP, Clark PMS, Cox LJ, Fall CHD, Osmond C, Winter PD (1991) Fetal and infant growth and impaired glucose tolerance at age 64. BMJ 303: 1019-1022

6. Phipps K, Barker DJP, Hales CN, Fall CHD, Osmond C, Clark PMS (1993) Fetal growth and impaired glucose tolerance in men and women. Diabetologia 36: 225-228

7. Lithell HO, McKeigue PM, Berglund L, Mohsen R, Lithell UB, Leon DA (1996) Relation of size at birth to non-insulindependent diabetes and insulin concentrations in men aged 50-60 years. BMJ 312: 406-410

8. Barker DJP, Hales CN, Fall CHD, Osmond C, Phipps K, Clark PMS (1993) Type II (non-insulin-dependent) diabetes mellitus, hypertension and hyperlipidaemia (syndrome $\mathrm{X}$ ): relation to reduced fetal growth. Diabetologia 36: 62-67

9. Hales CN, Barker DJP (1992) Type 2 (non-insulin-dependent) diabetes mellitus: the thrifty phenotype hypothesis. Diabetologia 35: 595-601

10. Garofano A, Czernichow P, Bréant B (1998) Postnatal somatic growth and insulin contents in moderate or severe intrauterine growth retardation in the rat. Biol Neonate 73: 89-98
11. Garofano A, Czernichow P, Bréant B (1998) Beta-cell mass and proliferation following late fetal and early postnatal malnutrition in the rat. Diabetologia 41: 1114-1120

12. Goto Y, Suzuki KI, Sasaki M, Ono T, Abe S (1988) GK rats as a model of nonobese noninsulin-dependent diabetes: selective breeding over 35 generations. In: Shafrir E, Renold AE (eds) Frontiers in diabetes research. Lessons from animal diabetes II. Libbey press, London, pp 301-303

13. Portha B, Serradas P, Bailbe D, Suzuki KI, Goto Y, Giroix MH (1991) B-cell insensitivity to glucose in the GK rat, a spontaneous non obese model for type II diabetes. Diabetes 40: 486-491

14. Movassat J, Saulnier C, Serradas P, Portha B (1996) Impaired development of pancreatic $\beta$-cell mass is a primary event during the progression to diabetes in the GK rat. Diabetologia 40: 916-925

15. Portha B, Serradas P, Blondel O, Giroix MH, Bailbe D (1990) Relation between hyperglycemia and impairment of insulin secretion and action. Information from the n-STZ rat models. In: Shafrir E (ed) VII. 1. Frontiers in diabetes research. Lessons from animal diabetes III. Smith-Gordon, UK, pp 334-341

16. Wang RN, Bouwens L, Klöppel G (1996) Beta-cell growth in adolescent and adult rats treated with streptozotocin during the neonatal period. Diabetologia 39: 548-557

17. Bonner-Weir S (1994) Regulation of $\beta$-cell mass in vivo. Recent Prog Horm Res 49: 91-104

18. Bonnevie-Nielsen V, Steffes MW, Lernmark A (1981) A major loss in islet mass and B-cell function precedes hyperglycemia in mice given multiple low doses of streptozotocin. Diabetes 30: 424-429

19. Scaglia L, Cahill C, Finegood D, Bonner-Weir S (1997) Apoptosis participates in the remodeling of the endocrine pancreas in the neonatal rat. Endocrinology 138: 1736-1741

20. Finegood DT, Scaglia L, Bonner-Weir S (1995) Dynamics of $\beta$-cell mass in the growing rat pancreas. Estimation with a simple mathematical model. Diabetes 44: 249-256

21. Petrik J, Arany E, Mc Donald TJ, Hill DJ (1998) Apoptosis in the pancreatic islet cells of the neonatal rat is associated with a reduced expression of insulin-like growth factor II that may act as a survival factor. Endocrinology 139: 2994-3004

22. Pick A, Clark J, Kubstrup C, Levisetti M, Pugh W, BonnerWeir S, Polonsky KS (1998) Role of apoptosis in failure of $\beta$ cell mass compensation for insulin resistance and $\beta$-cell defects in the male Zucker diabetic fatty rat. Diabetes 47: 358-364

23. Scaglia L, Smith FE, Bonner-Weir S (1995) Apoptosis contributes to the involution of $\beta$-cell mass in the post-partum rat pancreas. Endocrinology 136: 5461-5468

24. Bouwens L, Klöppel G (1996) Islet cell neogenesis in the pancreas. Virchows Arch 427: 553-560

25. Garofano A, Czernichow P, Bréant B (1997) In utero undernutrition impairs rat beta-cell development. Diabetologia 40: 1231-1234

26. Hales CN, Desai M, Ozanne SE, Crowther NJ (1996) Fishing in the stream of diabetes: from measuring insulin to the control of fetal organogenesis. Biochem Soc Trans 24: 341-350

27. Dahri S, Snoeck A, Reusens-Billen B, Remacle C, Hoet JJ (1991) Islet function in offspring of mothers on low-protein diet during gestation. Diabetes 40 [Suppl 1]: 115-120

28. Leger J, Levy-Marchal C, Bloch J et al. (1997) Reduced final height and indications for insulin resistance in 20 year olds born small for gestational age: regional cohort study. BMJ 315: 341-347

29. Eriksson UJ (1996) Lifelong consequences of metabolic adaptations in utero? Diabetologia 39: 1123-1125 